Szymon Dąbrowski

Uniwersytet Gdański

\title{
Krytyczna pedagogika religii - zarys problematyki
}

\section{Wstęp}

Celem tegoż artykułu jest przedstawienie zarówno genezy, jak i rozwoju pedagogiki religii $\mathrm{w}$ horyzoncie paradygmatu krytycznego. Głównym zadaniem jest tu ukazanie dociekań pedagogiczno-religijnych szczególnie w XX wieku, jako źródłowo zaangażowanych analiz w przestrzeni ideowo-krytycznej interpretacji. Jest tu mowa o tradycji niemieckiej pedagogiki religii, która powstała na początku XX wieku, a najintensywniej rozwinęła się w czasie międzywojennym dzięki postulatom teologii liberalnej i tendencjom emancypacyjnym ${ }^{1}$. Co ciekawe, postulaty krytycznej rewizji wychowania religijnego na gruncie Kościoła protestanckiego w Niemczech były zainicjowane oddolnie, przede wszystkim przez pedagogów i nauczycieli szkolnych. $Z$ kolei najważniejszymi przedstawicielami tego podejścia w środowisku naukowym byli Otton Baumgarden i Richard Kabisch, którzy bazując na pedagogice reformy wnosili emancypacyjne postulaty dotyczące eliminacji dominacyjnej pozycji Kościoła zarówno w życiu społecznym, jak i edukacyjnym $^{2}$. Edukacja religijna przez nich rozumiana nie miała wprost kształtować ludzkiej religijności, teologiczności, monoteistyczności czy nawet ewangeliczności, ale przede wszystkim miała na celu rozwój człowieczeństwa w możliwie doskonałej postaci jego boskiej konstrukcji. Były to tezy krytyczne wobec ówczesnego stanu wychowania i nauczania religijnego, przez co były niepopularne, wskazując jednocześnie, że pedagogika religii jest dziedziną niekorzystnie wpływającą na „interesy” Kościołów protestanckich. Ten etap rozwoju pedagogiki religii jako dziedziny naukowej - datowany na początek wieku XX - był powiązany z paradygmatem krytycznym, przede wszystkim na poziomie potocznego rozumienia tej kategorii. Z kolei bezpośrednie nawiązanie do myśli krytycznej - szczególnie teorii krytycznej, hermeneutyki i pedagogiki krytycznej - miało miejsce dopiero w drugiej połowie XX wieku, szczególnie dzięki osobom G. Otto, H.J. Dogera

\footnotetext{
1 Zob. Teologia liberalna, [w:] H.Vorgrimer, Nowy leksykon teologiczny wiara - objawianie - dogmat, Warszawa 2005, s. 380-381.

2 Zob. M. Konieczny, Emancypacja, [w:] Leksykon pedagogiki religii, red. C. Rogowski, Warszawa 2007, s. 157-161.
} 
i J. Lotta. Autorzy ci pierwsi zaproponowali radykalną zmianę paradygmatu w pedagogice religii z kerygmatycznej i konfesyjnej na ideologiczno-krytyczną. Polegało to w głównej mierze na przyjęciu kryteriów F.D. Schleiermachera, w odniesieniu do relacji między teorią pedagogiczną a praktyką wychowawczą, którym przysługuje całkowita odrębność ${ }^{3}$. W tym przypadku teoria nie musiała usprawniać czy poprawiać efektywności danej praktyki, ale przede wszystkim miała czynić ją bardziej świadomą - względem możliwie wszelkich uwarunkowań. Na gruncie edukacji religijnej miało to bardzo poważne konsekwencje, gdy teoria pedagogiczna odsłaniała i uświadamiała uwarunkowania filozoficzne, społeczne, ideowe, itd. w paradygmacie krytycznej interpretacji. W obrębie podstawowych założeń krytycznej pedagogiki religii w tymże tekście zaprezentowana będzie również problematyka na gruncie polskiej pedagogiki religii nurtu krytycznego, do której należą szczególnie prace Cypriana Rogowskiego - np. $\mathrm{w}$ obrębie hermeneutycznej interpretacji symbolu religijnego ${ }^{4}$ oraz prace Bogusława Milerskiego - np. wokół hermeneutycznej pedagogiki religii 5 .

\section{Pedagogika religii}

Wiek XIX dla pedagogiki religii, był momentem kluczowym, gdyż zaczęto systematycznie włączać kryteria analizy pedagogicznej w przestrzeń edukacji religijnej. Inicjatorem takiego podejścia był przede wszystkim F. Schleiermacher, filozof i teleolog ewangelicki żyjący jeszcze w XIX wieku, który w 1826 roku prowadził na Uniwersytecie w Berlinie wykłady z pogranicza pedagogiki i teologii. W swojej pracy z jednej strony podkreślał pilną potrzebę poszerzenia edukacji religijnej o wymiar empiryczny i duchowy, z drugiej zaś strony wnosił postulat otwarcia na współczesną humanistykę. Pomysł ten doprowadził w tamtym czasie do powstania założeń teologii liberalnej, polegającej przede wszystkim na odnowie i uwspółcześnieniu interpretacji tekstów biblijnych. Innymi zwolennikami reinterpretacji form edukacji religijnej byli Charles Palmer, który 1844 roku wydał dzieło o ewangelickiej katechetyce i pedagogice pt. Ewangelicka katechetyka, oraz Tuiskon Ziller, przedstawiciel herbartyzmu ${ }^{6}$. Obaj wnosili nie tylko o włączenie analiz humanistyki w przestrzeń religijną, ale przede wszystkim o skorelowanie w równym stopniu wpływu nauk społecznych i teologii. Stanowisko liberalnych teologów w kolejnych latach doprowadziło do żywego sprzeciwu tzw. ruchu kerygmatycznego, którego propagatorami byli Karl Barth (1886-1968) i Gabriel Bohne (1885-1977), uznający pierwotność i nadrzędność objawienia zawartego w Biblii względem całego procesu kształcenia7.

\footnotetext{
Zob. M. Patalon, Teologia a pedagogika, [w:] Leksykon pedagogiki religii..., s. 786-790.

Zob. C. Rogowski, Pedagogika religii. Podręcznik akademicki, Torun 2011.

Zob. B. Milerski, Hermeneutyka pedagogiczna. Perspektywy pedagogiki religii, Warszawa 2011.

B. Milerski, Pedagogika religii, [w:] Religia, Encyklopedia PWN, t. 8, s. 51-53.

M. Patalon, Teologia a pedagogika, [w:] Leksykon pedagogiki religii..., s. 786-790.
} 
Pojęcie pedagogika religii jako nazwę dziedziny łączącej zakres badań teologii i pedagogiki wprowadził jako pierwszy niemiecki teolog i filozof Max Reischle. Uznał on w swojej rozprawie Pytanie o istotę religii. Podstawy metodologiczne filozofii religii, wydanej w Freiburgu w 1889 r., że pedagogika religii nie jest dziedziną samodzielną z zakresu religioznawstwa, należy natomiast do nauk teologicznych ${ }^{8}$. Dzieje się tak dlatego, że analizy wchodzące w jej skład zawsze uwarunkowane są rozumieniem w kontekście konkretnej konfesji. Zagadnienia nauczania i wychowania religijnego mają swoje miejsce w strukturze teologii pastoralnej, jako dziedziny katechetyki. W tym samym czasie $\mathrm{w}$ nieco innym tonie wypowiadali się Otton Baumgarten i Richard Kabisch, którzy w swoich pracach inicjowali nowe podejście do edukacji religijnej, opartej na teologii liberalnej i procesach emancypacji w kulturze. Głównym ich postulatem była potrzeba odróżnienia katechezy kościelnej od szkolnego nauczania religii, które miało łączyć się z edukacją humanistyczną, uprawianą w obrębie edukacji powszechnej. W tym rozumieniu szkolna edukacja religijna nie miała nadrzędnego, konfesyjnego celu, ale przede wszystkim cel ogólnokulturowy9.

W kolejnych latach katechetyka zarówno katolicka, jak i protestancka coraz szerzej otwierała się na osiągnięcia takich nauk, jak pedagogika czy psychologia. Na początku XX wieku O. Eberhardt oraz J. Gottler spostrzegli stopniową autonomizację problematyki i metody pedagogiki religii $\mathrm{w}$ strukturze katolickich nauk teologicznych. Wydaje się, iż pedagogika religii $\mathrm{w}$ tamtym okresie rozwijała się coraz intensywniej, im mocniej uobecniała się krytyka tradycyjnej roli religii, a w szczególności roli Kościoła we współczesnym społeczeństwie. Potrzeba szybkich zmian zarówno języka, jak i treści religijnego przekazu, doprowadziły do stopniowej autonomizacji treści pedagogicznych wewnątrz teologii pastoralnej ${ }^{10}$. W tym też okresie wokół rozumienia i potrzeb pedagogiki religii narastała żywa dyskusja, wielu teologów i filozofów różnie rozumiało miejsce, cele i zadania dla rodzącej się już samodzielnej dziedziny. Jednym z nich był Friedrich Niebergall, który w 1911 roku opublikował manifest pt. Rozwój katechetyki w kierunku pedagogiki religii ${ }^{11}$. W tekście tym ukazywał on nowatorskość i niezależność analiz wchodzących w skład pedagogiki religii od klasycznej protestanckiej katechetyki, oraz wnioskował potrzebę tworzenia nauki ogarniającej relację między pedagogiką i teologią, z dominującym uwzględnieniem samej pedagogiki. Było to jeden z pierwszych pomysłów zbudowania metodologicznie niezależnej od protestanckiej teologii dziedziny pedagogicznej działającej na rzecz pracy katechetycznej opartej jednak przede wszystkim na kryteriach nauk o wychowaniu. Od tego momentu można zanotować początek dużego ruchu intelektualnego w obrębie kate-

\footnotetext{
8 M. Reischle, Die Frage nach dem Wesen der Religion. Grundlegung zu einer Methodologie der Religionsphilosophie, Freiburg 1889.

B. Milerski, Pedagogika religii, [w:] Pedagogika, subdyscypliny i dziedziny wiedzy o edukacji..., s. 45-68; C. Rogowski, Pedagogika religii, [w:] Leksykon pedagogiki religii..., s. 561-565.

10 B. Milerski, Pedagogika religii, [w:] Pedagogika, subdyscypliny i dziedziny wiedzy o edukacji..., s. 47-49.

11 F. Niebergall, Die Entwicklung der Katechetik zur Religionspädagogik, Berlin 1911.
} 
chetyki protestanckiej, zmierzającego do zbudowania pedagogiki religii rozumianej jako dziedzina autonomiczna wobec teologii, a szeroko wykorzystującej analizy i rozstrzygnięcia z zakresu pedagogiki i psychologii ogólnej ${ }^{12}$. Podobnie wyglądała sytuacja po stronie katolickich teologów, gdzie Joseph Göttler, kierownik katedry pedagogiki i katechezy katolickiej na uniwersytecie w Monachium, wydał prace $\mathrm{w}$ duchu pedagogiczno-religijnym. Istnieje jednak $\mathrm{w}$ tamtym czasie, różnica między protestanckim a katolickim rozumieniem nowej dziedziny, gdzie ta pierwsza sytuuje pedagogikę religii jako samodzielną naukę pedagogiczną, natomiast druga, wprost uzależnia ją od katechetyki, której ma służyć jako odnowa metodologiczna ${ }^{13}$.

Efektem pracy na rzecz odnowienia i uwspółcześnienia niemieckojęzycznej edukacji religijnej było powołanie nowych periodyków i czasopism stricte poświęconych zagadnieniom pedagogicznoreligijnym, m.in. "Christlich-Pädagogische Blatter" wydawany w Wiedniu, „Katechetische Blatter” oraz „Zeitschrift fur den Evangelischen Religionsunterricht” $\mathrm{i}$ „Monatsblatter für den Evangelischen Religionsunterricht", wydawane jednak tylko do lat trzydziestych. Główną problematyką tamtego czasu był, po pierwsze, wewnętrzny rozwój całej katechetyki chrześcijańskiej, po drugie, zbudowanie współczesnej, otwartej na aktualne problemy i dylematy człowieka XX wieku edukacji religijnej, oraz po trzecie, kontestacja dominacji Kościoła ewangelickiego w społeczeństwie demokratycznym. Rozwój edukacji religijnej w tym przypadku był rozumiany jako wypracowanie narzędzi skutecznego przekazu treści religijnych, które odpowiadałyby nieustannie zmieniającej się sytuacji religijno-społecznej. Zmiany te dotyczyły zarówno języka przekazu, jak i reinterpretacji i uwspółcześnienia treści teologicznych. Pomysł stworzenia nauki pedagogicznej pracującej na rzecz współczesnej, otwartej edukacji religijnej, miał polegać przede wszystkim na wypracowaniu jak najskuteczniejszych modeli edukacyjnych. Kształt tych modeli był modyfikowany i zależny od aktualnych potrzeb społeczno-kulturowych, natomiast z założenia miał być możliwy do zastosowania przez różne kościoły chrześcijańskie w pluralistycznym społeczeństwie ${ }^{14}$.

Rozwój pedagogiki religii w Niemczech został zahamowany w latach trzydziestych z powodu sytuacji polityczno-społecznej, gdzie państwo nazistowskie wykorzystując edukację religijną do celów ideologicznych, zredukowało jej metodologiczny i naukowy kontekst. Jednocześnie w latach międzywojennych dużą popularnością cieszył się w protestanckiej teologii nurt kerygmatyczny reprezentowany przez teologów katolickich i protestanckich, np. J.A. Jungmanna, G. Bohne, O. Hammelsbecka czy H. Kittela. Podejście to z założenia w dużej części

12 Zob. B. Milerski, Nurty w ewangelickiej pedagogice religii w XX wieku, [w:] Paedagogia Christiana, t. 8, 2001; Tenże, Elementy pedagogiki religijnej. Status edukacji religijnej w Niemczech, Warszawa 1998.

13 B. Milerski, Pedagogika religii, [w:] Pedagogika, subdyscypliny i dziedziny wiedzy o edukacji..., s. 49.

14 J. Bagrowicz, Edukacja religijna wspótczesnej młodzieży, Torun 2000, s. 275-289. 
eliminowało z zakresu analiz teologii kontekst współczesnej problematyki pedagogicznej ${ }^{15}$.

W kolejnych dekadach XX wieku, już od lat pięćdziesiątych pedagogika religii jako dyscyplina naukowa uzyskiwała coraz większe znaczenie w kontekście wyzwań i procesów społecznych, takich jak: rewolucja kulturowa, modernizacja życia rodzinnego, liczne procesy emancypacyjne, sekularyzacja i krytyka niedemokratycznej władzy w Kościele. Już w 1948 roku powołano w Niemczech czasopismo "Der Evangelische Erzieher", łączące badania teologii i pedagogiki, a w 1954 roku Kościół ewangelicki utworzył centrum Munster Comenius-Instytut, w którym pracowano na rzecz interdyscyplinarnych badań łączących analizę kategorii teologicznych ze współczesnymi teoriami wychowania. Bardzo intensywna krytyka teologii dialektycznej ${ }^{16} \mathrm{i}$ kerygmatycznej koncepcji wychowania ${ }^{17} \mathrm{~W}$ tamtym czasie doprowadziła do powstania nowych teorii i modeli edukacji religijnej, wprost czerpiącej z systemów antropologii filozoficznej. Chodzi przede wszystkim o prace Martina Stallmanna, Hansa Stocka, Gerta Otto oraz w kolejnych latach Hansa-Bernharda Kaufmanna, Dietera Stoodta, Klausa Wegenasta, wprowadzające metodę hermeneutyczną, fenomenologiczną i emancypacyjno-krytyczną do edukacji religijnej ${ }^{18}$. Dekady lat siedemdziesiątych i osiemdziesiątych w Niemczech były okresem stabilizacji i szybkiego instytucjonalnego rozwoju na uniwersytetach i w państwowych instytucjach pedagogiki religii. W tym też czasie zaczęto oficjalnie posługiwać się pojęciem ewangelicka pedagogika religii, oznaczającym dziedzinę nauk pedagogicznych łączącą teologię protestancką z teorią wychowania. Również w obrębie Kościoła katolickiego rozpoczęto kształcenie w zakresie katechetyki otwartej na projekty współczesnej teorii edukacji. W 1984 roku powołano czasopismo "Jahrbuch der Religionspädagogik", które na stałe w zakres badań pedagogiczno-religijnych wprowadziło kategorię ponadkonfesyjności, otwartości, dialogu międzyreligijnego i ekumenicznego ${ }^{19}$.

Odmienną tradycją kulturowo-językową była pedagogika religii uprawiana w Stanach Zjednoczonych, gdzie początkowo zdominowana przez protestanckich teologów, ale szybko uzyskała charakter interdyscyplinarny i ekumeniczny. Stało się to jednak dlatego, gdyż wyrosła na gruncie już uprawianej edukacji reli-

15 Zob. J. Bagrowicz, Problematyka katechizacji młodzieży w nurcie katechezy kerygmatycznej, „Studia Theologica Varsaviensia" 1996, 34, nr 1, s. 183-200.

16 Teologia dialektyczna to okres w rozwoju teologii XX wieku datowany na lata 1920-1933, do którego należą: Karl Barth, Eduard Thurneysen, Friedrich Gogarten, Emil Brunner, Rudolf Bultmann oraz Georg Merz. Koncepcja ta była sprzeciwem wobec teologii liberalnej początku XX wieku, oraz starała się odpowiadać na egzystencjalno-teologiczne problemy związane z wydarzeniami I wojny światowej. Zob. M. Patalon, Teologia a pedagogika, [w:] Leksykon pedagogiki religii..., s. 786-790.

17 Kerygmatyka to kierunek $\mathrm{w}$ teologii katolickiej łączący teologię systematyczną z pastoralną, w celu skutecznego oddziaływania na rozwój wiary wspólnoty chrześcijańskiej. Zob. J. Bagrowicz, Problematyka katechizacji młodzieży w nurcie katechezy kerygmatycznej...,s. 183-200.

18 Zob. B. Milerski, Pedagogika religii, [w:] Religia, Encyklopedia PWN..., s. 52-53.

19 C. Rogowski, Czasopisma pedagogicznoreligijne niemieckojęzyczne, [w:] Leksykon pedagogiki religii..., s. 89-90. 
gijnej opartej na tzw. szkolnictwie niedzielnym, działającym od połowy XVIII wieku. Była to inicjatywa purytańskich kościołów angielskich i kolonialnych, które organizowały nauczanie dla dzieci w niedziele, jako jedynym dniu wolnym od pracy. Inicjatorem tego ruchu był angielski teolog R. Raikes (1736-1811), który prowadził naukę dla dzieci przede wszystkim w zakresie wiedzy religijnej, ale również wiedzy ogólnej. Początkowo odbywało się to na płaszczyźnie międzykościelnej, następnie na płaszczyźnie międzywyznaniowej, gdzie nauczycielami były osoby świeckie. W 1803 roku w Wielkiej Brytanii powstał London Sunday School Union (Londyński Związek Szkół Niedzielnych), który w 1880 roku obejmował nauką 12 milionów uczniów. W 1824 roku w Filadelfii powołano The American Sunday School Union (Amerykańska Unia Szkół Niedzielnych), której organizacyjnym celem działania było powołanie szkoły w każdej amerykańskiej miejscowości. W kolejnych dekadach zasięg szkolnictwa niedzielnego obejmował już całe Stany Zjednoczone ${ }^{20}$.

Pod koniec XIX wieku ujawniła się potrzeba głębokiej dyskusji i refleksji w obrębie edukacji religijnej, czego wynikiem było powołanie w 1903 roku The Religious Education Association - REA (Stowarzyszenie Edukacji Religijnej). Przewodniczącym został William R. Harper - prezydent Uniwersytetu w Chicago, który w swoim odczycie nakreślił otwarty i naukowy charakter działalności stowarzyszenia. Kolejnym prelegentem pierwszego zjazdu był George A. Coe, jeden z prekursorów dialektycznej wizji edukacji religijnej. Koncepcja ta polegała na binarnej perspektywie antropologicznej, uznającej człowieka jako byt jednocześnie społeczny i religijny. W pierwszym rozumieniu człowiek-dziecko zajmuje centralne miejsce $\mathrm{w}$ systemie kształcenia szkolnego, ale jednocześnie posiada głęboką naturę aksjologiczną i transcendentny punkt odniesienia. W tym przypadku pedagogika religii służy dialektycznej edukacji religijnej rozumianej jako jeden $\mathrm{z}$ istotnych elementów całościowego procesu kształcenia. W pierwszym zjeździe uczestniczył również John Dewey, który w swoim odczycie postulował, aby wszelkie badania $\mathrm{w}$ zakresie pedagogiki religii spełniały identyczne metodologicznie warunki, jak pozostałe badania o charakterze edukacyjnym. Z powyższej dyskusji wyłonił się jeden najistotniejszy wniosek, mianowicie, współczesna edukacja religijna winna rozwijać się równolegle z edukacją powszechną, spełniając tożsame naukowe, jak i społeczne kryteria weryfikacji21.

Na kolejnych, corocznych zjazdach sformułowano jednorodny cel edukacji religijnej, którym była wzajemna, dwustronna korelacja wymiaru religijnego i edukacyjnego zarówno w przestrzeni naukowej, jak i społecznej. W 1906 roku w Chicago powołano czasopismo „Religious Education”, które stało się centralnym ośrodkiem rozwoju amerykańskiej otwartej i ekumenicznej myśli edukacyjno-religijnej. W 1917 roku G.A. Coe opublikował pierwszą na gruncie amerykańskim

20 Zob. M. Patalon, Teologia a pedagogika, [w:] Leksykon pedagogiki religii..., s. 786-790.

21 Zob. B. Milerski, Pedagogika religii, [w:] Pedagogika, subdyscypliny i dziedziny wiedzy o edukacji..., s. $47-48$. 
pracę $\mathrm{w}$ zakresie pedagogiki religii pt. Social Theory of Religuos Education (Społeczna teoria edukacji religijnej). Była ona poświęcona teoretycznym założeniom edukacji religijnej, które nie sprowadzały się wyłącznie do nauk społecznych czy teologicznych, ale były autonomicznym połączeniem dwóch źródłowych nauk jednocześnie ${ }^{22}$.

Obok REA w 1931 roku środowisko katolickich naukowców powołało do istnienia "Journal of Religious Instruction", przekształcony w 1947 w "Catholic Educator". W tym także czasie włączono w badania edukacyjnoreligijne analizy z zakresu psychologii, gdzie Granville S. Hall utworzył „American Journal of Religious Psychology and Education". W kolejnych latach działacze REA doprowadzili do szerokiego zainteresowania problematyką edukacji religijnej w zakresie szkolnictwa wyższego, dzięki czemu na uniwersytetach zaczęły powstawać instytuty i katedry pedagogiki religii uprawianej w obrębie religioznawstwa. Lata siedemdziesiąte i osiemdziesiąte poprzedniego stulecia na gruncie amerykańskim to czas nie tylko dialogu na rzecz wspólnej edukacji religijnej między wyznaniami chrześcijańskimi, ale również to otwarcie pedagogiki religii na dialog interreligijny, w tym szczególnie chrześcijaństwa z judaizmem, islamem czy religiami wschodu, a w kolejnym etapie kulturowy dialog religii z ateizmem ${ }^{23}$.

Ostatnie dekady XX wieku przyniosły również duże pobudzenie na gruncie brytyjskiej pedagogiki religii, która w odróżnieniu od tradycji amerykańskiej i niemieckiej nie posiadała bogatej naukowej przeszłości. Dopiero w latach osiemdziesiątych za sprawą anglikańskiego działacza oświatowego Johna Hulla ruszyła praca na rzecz instytucjonalnej budowy pedagogiki religii jako dziedziny naukowej. Od roku 1971, w którym Hull stał się redaktorem naczelnym czasopisma "The British Journal of Religious Education", ruszyła praca na rzecz budowy naukowych podstaw $\mathrm{w}$ anglikańskiej pedagogice religii. $\mathrm{W}$ tym także czasie dynamicznie powstawały instytuty i katedry pedagogiki religii, które jednak nie były powoływane na wydziałach teologicznych czy studiów nad religią, ale właśnie na wydziałach edukacyjnych i pedagogicznych. Brytyjska edukacja religijna stała się mocnym filarem $\mathrm{w}$ przestrzeni międzynarodowych badań interdyscyplinarnych $^{24}$. Druga połowa XX wieku była dla pedagogiki religii jako subdyscypliny naukowej czasem bardzo intensywnego rozwoju, stworzono nowe koncepcje edukacyjne, w których zarówno pedagogika, jak również filozofia, psychologia czy socjologia wprowadzały nowe wymiary analiz. Jest tu mowa przede wszystkim o hermeneutycznej, egzystencjalnej i emancypacyjno-krytycznej pedagogice religii, a także powstałej w kolejnych latach psychologii religii odsłaniającej nieświadome, przez co nieobecne do tej pory wymiary badań w zakresie edukacji religijnej. $W$ kolejnych latach, pod koniec $X X$ wieku, pedagogika religii rozwijająca się przede wszystkim na gruncie anglojęzycznym i niemieckojęzycznym

\footnotetext{
Ibidem, s. 48.

Ibidem, s. 54.

Ibidem, s. 48.
} 
uzyskuje status dziedziny samodzielnej. Powstające instytuty i katedry stawały się placówkami naukowymi, dzięki czemu otwierała się możliwość współpracy międzykulturowej.

Sytuacja kulturowo-polityczna końca poprzedniego wieku w krajach demokratycznych była bardzo zróżnicowana, a społeczeństwa zmagały się z wieloma problemami wynikającymi ze zmian kulturalno-społecznych. W tej dynamicznej strukturze również religia, jak i poszczególne Kościoły na nowo poszukiwały swojego miejsca w hierarchii społecznej. W sytuacji tej pedagogika religii stała się dziedziną autorefleksyjną oraz krytyczną, również wobec religii jako takiej. Edukacja powszechna, której część stanowiły również zajęcia z religii, wymagała, by zarówno treści, jak i cele edukacji religijnej były spójne z podstawowymi założeniami i organizacją społeczeństwa pluralistycznego. Poszczególne Kościoły narodowe zostały postawione przed faktem działania na rzecz współczesnego społeczeństwa, jednocześnie odpowiadając na indywidualne i grupowe potrzeby. Kategorie takie, jak tolerancja, wolność, równość, różnorodność, itp. nie były już tylko hasłami z przeszłości, ale stały się codzienną rzeczywistością krajów Europy Zachodniej i całego świata. W tej oto sytuacji religie świata oraz Kościoły narodowe poszukiwały współczesnego narzędzia przekazu, umożliwiającego włączenie się w debatę o wyzwaniach społeczeństwa XXI wieku²5.

W obecnej sytuacji termin pedagogika religii jest kategorią niejednoznaczną, z kilku co najmniej powodów. Po pierwsze, istnieje kilka odmiennych tradycji językowych, z których najważniejszymi są niemiecko- i anglojęzyczna tradycja. Po drugie, jest to pojęcie stosunkowo młode, $w$ aktualnym rozumieniu obecne $w$ naukach dopiero od połowy XX w. Po trzecie, nie ma zgody co do wzajemnej relacji i granic między dziedzinami wchodzącymi w skład pedagogiki religii, mianowicie pedagogiką i teologią. Po czwarte - co wprost wynika z poprzedniego - brak zgody wobec relacji między powyższymi dziedzinami skutkuje niejednorodną treścią wchodzącą w skład analiz i badań pedagogicznoreligijnych ${ }^{26}$.

Językowa różnorodność pojęcia pedagogiki religii nie wynika tylko z wielości tłumaczeń, ale również z różnego rozumienia i interpretacji tak bliskich pojęć, jak: katechetyka, nauka religii w szkole, edukacja religijna, no i właśnie pedagogika religii. W tradycji niemieckojęzycznej, z której pojęcie to pierwotnie pochodzi, sytuacja jest dość klarowna, gdyż między pedagogiką religii - Religionspädagogik a katechetyką - Katechetic, istnieje różnica przedmiotowa. Pojęcia te w historii niemieckiej pedagogiki i teologii zawsze miały inny przedmiot i znaczenie, mówiąc najprościej, katechetyka przynależała do danej konfesji i służyła jej celom, natomiast pedagogika religii przynależała procesowi edukacji religijnej od strony kontaktu z instytucją państwa. Inaczej ma się sytuacja w tradycji anglojęzycznej, gdzie wprost pojęcie pedagogika religii nie występuje, a jest zastępowane pojęciem edukacja religijna - Religious education bądź teoria edukacji religijnej-Theory

\footnotetext{
25 Tenże, Elementy pedagogiki religijnej, Warszawa 1998.

26 Zob. C. Rogowski, Pedagogika religii, [w:] Leksykon pedagogiki religii..., s. 561-598.
} 
of religious education. Oba pojęcia oznaczają dziedzinę praktycznej i teoretycznej refleksji pedagogicznej o przedmiocie religia, natomiast pojęcie katechetyka -cathetetic oraz nauczanie religii - religius instruction są pojęciami sporadycznie używanymi i przynależą jako narzędzie ewangelizacji do danego Kościoła czy konfesji. Sytuacja w Polsce jest dużo bardziej zróżnicowana, szczególnie z uwagi na obecnie toczącą się dyskusję między przedstawicielami katechetyki i pedagogiki religii. Polemika ta, najprościej rzecz ujmując, polega na postawieniu granicy między teologią i pedagogiką $\mathrm{w}$ analizie edukacyjnej oraz na uznaniu bądź odrzuceniu niezależności powyższych dziedzin względem siebie ${ }^{27}$.

Rozwój i status pedagogiki religii w Polsce wprost zależał od uwarunkowań prawnych lekcji religii w powszechnej edukacji państwowej. W Polsce $\mathrm{w} X X$ wieku, przed II wojną światową na podstawie konstytucji z 1921 roku, religia była przedmiotem obowiązkowym na wszystkich poziomach edukacji dla uczniów, którzy nie ukończyli 18 roku życia. Konkordat z 1925 roku wskazywał na szczególną i dominującą rolę Kościoła rzymskokatolickiego w strukturze II Rzeczypospolitej. Po wojnie już od 1945 roku sytuacja zaczęła radykalnie się zmieniać, gdy początkowo na mocy dekretu Tymczasowego Rządu Jedności Narodowej przestał obowiązywać konkordat. Następnie w 1952 roku został wprowadzony całkowity rozdział Kościoła od państwa, co w konsekwencji doprowadziło do usunięcia lekcji religii z polskich szkól. Od roku 1961/1962 lekcje religii odbywały się tylko jako zajęcia pozalekcyjne, poza obrębem budynków oświatowych. Sytuacja ta trwała do roku 1989, kiedy po wydarzeniach zmian ustrojowych religia ponownie wróciła do szkół. Dopiero w latach dziewięćdziesiątych XX wieku w Polsce pojawia się po raz pierwszy w dyskusjach pedagogicznych pojęcie pedagogiki religii, mimo iż analizy w tym zakresie były obecne znacznie wcześniej. Należy tu odnotować postać Walentego Gadowskiego, który już na początku XX wieku postulował pogłębienie katolickiej katechezy o źródłowy kontekst pedagogiczny. Jak również w latach trzydziestych na gruncie ewangelickim Karol Banszel, pragnący zrealizować pomysł otwarcia katedry pedagogiki religii na wydziale teologii ewangelickiej. W tym też czasie Sergiusz Hessen wskazywał nowe źródła i potrzeby rozwoju w polskiej edukacji religijnej. Po II wojnie światowej szczególnie w naukowych środowiskach KUL-u odnaleźć można prace z zakresu edukacji religijnej, uprawianej jednak wyłącznie $\mathrm{w}$ duchu konfesji katolickiej. W latach siedemdziesiątych Stefan Kunowski, co prawda wprost nie odwołując się do źródeł europejskiej pedagogiki religii, ale poprzez łączenie analizy doktryny katechetycznej Kościoła rzymskokatolickiego z dorobkiem pedagogiki humanistycznej tworzy podwaliny polskiej pedagogiki religii. Za kolejnego prekursora można uznać Janusza Tarnowskiego, który w osiemdziesiątych latach z perspektywy pedagogicznej, uwzględniając kontekst filozoficzny i teologiczny opisuje teorię wychowania chrześcijańskiego. Obok badań stricte pedagogicznych należy odnotować prace z zakresu katechetyki, które zostały wzbogacone

27 Zob. J. Bagrowicz, Pedagogika religii, [w:] Encyklopedia pedagogiczna XXI wieku..., s. 242-249. 
szerokim kontekstem metodologicznym, jak i bogatą perspektywą antropologiczną. Jest tu mowa o pracach Mariana Finke, Mieczysława Majewskiego, Jana Charytańskiego, a także Władysława Kubika, gdzie ten ostatni zapoczątkował program dydaktyki katechetycznej. Od tego momentu można mówić, że polska edukacja religijna rozwijała się $\mathrm{w}$ dwóch niezależnych wymiarach, pierwszym był nurt katechetyki tradycyjnej, opierający się przede wszystkim na źródłach katechetyki i teologii pastoralnej, drugim nurt pedagogiki religii, posługujący się źródłami zarówno z dziedziny religioznawstwa i pedagogiki, jak i filozofii, socjologii i psychologiii 28 .

Do dnia dzisiejszego toczą się liczne polemiki i dyskusje edukacyjno-polityczne dotyczące statusu i zakresu edukacji religijnej w państwie polskim. Dopiero na przestrzeni ostatnich dwudziestu lat obserwujemy dużą aktywność w opracowaniach naukowych otwartych na dorobek i bogactwo europejskiej i światowej pedagogiki religii. Sytuacja społeczno-polityczna ostatnich lat umożliwiła prowadzenie edukacyjnych analiz i badań w obrębie pedagogiki religii, niezależnie od badań katechetyki. Dzięki temu pojawiła się świadomość pilnej potrzeby reinterpretacji statusu i zasięgu edukacji religijnej w nowej rzeczywistości. Odnowa edukacji religijnej wydała się konieczna, z uwagi na dynamiczne zmiany społeczeństwa polskiego po roku 1989, ale również dokonana re-konfiguracja statusu Kościoła rzymskokatolickiego we współczesnym społeczeństwie. Dyskusja w zakresie zmian edukacji religijnej trwa do dziś i jak się wydaje - niezależnie od kontekstu politycznego - koncentrując się na analizach i badaniach naukowych. Pedagogika religii, jak również katechetyka, znalazły się w realnym impasie wobec rozumienia i odpowiedzi na potrzeby społeczeństwa polskiego XXI wieku. Kryzys ten, jak się wydaje, wynika z kilku co najmniej powodów:

- po pierwsze, istnieje niejawny spór między zwolennikami i przeciwnikami pedagogiki religii i katechetyki, który uniemożliwia transponowanie wiedzy teoretycznej i praktycznej z jednego kontekstu w drugi;

- po drugie, istnieje stała, zamknięta postawa Kościoła rzymskokatolickiego względem teoretycznych modeli współczesnej edukacji i praktycznych postulatów ich realizacji;

- po trzecie, kontekst dyskursu na temat edukacji religijnej, zdeterminowany jest relacją władzy i polityki, a zmarginalizowana jest kwestia metodologii nauk społecznych, w tym szczególnie nauk o wychowaniu, nauk psychologicznych i socjologicznych;

- po czwarte, edukacja religijna oparta na pedagogice religii jest wciąż dziedziną nową, która w kontekście polskiej pedagogiki nie ma statusu dziedziny samodzielnej. 


\section{Paradygmaty pedagogiki religii}

Przedstawiciele współczesnej pedagogiki religii, czerpiąc z szeroko rozumianej teologii religiii29, różnych systemów filozoficznych ${ }^{30}$, a także z dorobku pedagogiki kultury ${ }^{31}$ oraz pedagogiki krytycznej ${ }^{32}$ tworzą własne, autorskie koncepcje teoretyczne. Obejmują one rozumienie wychowawczej działalności konkretnych Kościołów, ale również analizują religijny wymiar ogólnej edukacji humanistycznej opartej na określonej antropologii, odpowiadającej aktualnym przemianom społeczno-kulturowym. Przede wszystkim są to prace z zakresu pedagogiki i filozofii wychowania, obejmujące konkretną przestrzeń treści religijnych, danego wyznania lub Kościoła. Współczesna pedagogika religii na świecie jest mocno zróżnicowana i niejednorodna, odmienności pojawiają się zarówno od strony kulturowo-językowej, ale także od strony przedmiotowo-problemowej. W tym miejscu należy wymienić środowiska czy też pewne paradygmaty myśli pedagogicznoreligijnej. Pierwszą płaszczyzną jest tu amerykańska pedagogika religii szczególnie uwzględniająca sytuację w Stanach Zjednoczonych, drugą europejska pedagogika religii obejmująca niemieckojęzyczne badania w Niemczech, Austrii i Szwajcarii oraz kontekst badań krajów skandynawskich, a także anglojęzyczne analizy w Wielkiej Brytanii. W paradygmacie badań europejskich znajdują się również nieliczne badania polskiej pedagogiki religii.

Amerykańska pedagogika religii uprawiana w Stanach Zjednoczonych ma tradycje sięgające XIX wieku i wcześniej. Dziś przede wszystkim opiera się na trzech fundamentach, neopragmatycznej filozofii, psychologii religii i kulturoznawstwie. Źródłowe badania pedagogiczne z zakresu psychologii religii pod koniec XX prowadził J. W. Fowler, profesor teologii i antropologii w Emor University w Atlancie, zaś w nurcie teorii krytycznej opartej na analizie kulturoznawczej Daniel S. Schipani. Bardzo istotnym wydarzeniem w przestrzeni badań pedagogiczno-religijnych było w 2003 roku połączenie się The Religious Education Association, tzw. REA, z The Association of Professors, and Researchers in Religious Education, tzw. APRRE, w jedną instytucję REA:APRRE działającą na rzecz badań ekumenicznych i interreligijnych na kontynencie Ameryki Północnej. Organizacja ta skupiła nie tylko profesorów i pracowników naukowych, ale rów-

29 Zob. J. Pawlik, Teologia religii, [w:] Leksykon pedagogiki religii..., s. 797-799; Teologia religii, Chrześcijański punkt widzenia, red. G. Dziewulski, Łódź-Kraków 2007; M. Patalon, Pedagogika ekumenizmu..., s. 159-171.

30 Zwłaszcza jest tu mowa o filozofii dialogu, egzystencjalizmie, fenomenologii, hermeneutyce czy filozofii personalistycznej. Zob. M. Buber, Ja i Ty. Wybór pism filozoficznych, tłum. J. Doktór, Warszawa 1992; E. Levinas, Całość i nieskończoność: esej o zewnętrzności, tłum. M. Kowalska, Warszawa 1998; J. Tischner, Filozofia dramatu, Kraków 1990; M. Heidegger, Bycie i czas, tłum. B. Baran, Warszawa 1994; H.G. Gadamer, Prawda i metoda. Zarys hermeneutyki filozoficznej, tłum. B. Baran, Warszawa 2004.

31 Zob. B. Milerski, Pedagogika kultury, [w:] Pedagogika, podręcznik akademicki.., s. 220-231.

32 Zob. T. Szkudlarek, Ibidem, s. 363-377. 
nież środowiska nauczycieli i duchownych przedstawicieli największych religii świata. Obecnie najważniejszymi działaczami na gruncie edukacji religijnej są m.in. L.M.A. Bowman, Th. Brelsford, R.H. Cram, P. Gilmour, B.A. Keely, R. Nishioka, E.B. Price, A.C. Vrame, A.S. Wimberly, którzy tworzą metodologiczną i systemową bazę tej dziedziny na gruncie amerykańskim ${ }^{33}$.

Duże znacznie $w$ europejskiej pedagogice religii odgrywała od samego początku do dnia dzisiejszego jej niemieckojęzyczna tradycja. Jak się wydaje, kluczowym etapem rozwoju tej dziedziny był okres po Soborze Watykańskim II, szczególnie na przełomie lat siedemdziesiątych i osiemdziesiątych, gdy nastąpiło wzajemne otwarcie katolickich i ewangelickich ośrodków badawczych z Niemiec, Austrii, Szwajcarii, a także krajach skandynawskich. Umownie rzecz ujmując, proces ten rozpoczął się w 1978 roku w Niemczech, gdzie środowisko katolickich pedagogów religii powołało do istnienia czasopismo "Religionspädagogische Beiträge. Zeitschrift der Arbeitsgemeinschaft Katholischer Katechetik-Dozenten", wydawane w Kaarst, następnie Kassel, a obecnie pod patronatem Arbeitsgemeinschaft Katholische Religionspädagogik Katechetik (AKRK) w Moguncji. Następnie w 1991 roku w Austrii w Graz powstaje "Osterreichisches Religionspädagogische Forum" wzmacniające współpracę przedstawicieli rożnych konfesji chrześcijańskiej pedagogiki religii. Jeszcze w 1982 roku środowisko ewangelickich pedagogów zainicjowano powstanie czasopisma "Schulfach Religion” w Wiedniu, w którego tworzenie obecnie włączył się Wydział Teologii Uniwersytetu Wiedeńskiego. Od roku 1984 w Neukirchen-Vluyn w Niemczech wydawany jest rocznik "JJahrbuch der Religionspädagogik”, w którym otwarcie prezentowane są ekumeniczne treści i promowany jest dialog między katolicką a protestancką pedagogiką religii. Ważną rolę w rozwoju ewangelickiej teorii edukacyjnej odegrał Karl E. Nipkow, profesor Uniwersytetu w Tybindze. Obecnie w europejskich krajach niemieckojęzycznych na wielu uniwersytetach i szkołach wyższych o profilu teologicznym i pedagogicznym obecne są instytuty i katedry pedagogiki religii. Aktualnie do najistotniejszych przedstawicieli ewangelickiej pedagogiki religii należą: G. Adam, Peter Biehl, H.-J. Fraas, J. Lahnemann, Michael Meyer-Blanck, G. Schmidt, Heinz Schmidt, Friedrich Schweitzer, do katolickiej natomiast: G. Bitter, Anton A. Bucher, Rudolf Englert, Norbert Mette, Hans-Georg Ziebertz, H.A. Zwergel $^{34}$.

Podobnie wygląda sytuacja $\mathrm{w}$ tradycji anglosaskiej, gdzie pedagogika religii najintensywniej rozwinęła się w latach osiemdziesiątych XX wieku, głównie za sprawą Johna M. Hulla z Wydziału Edukacji Uniwersytetu w Birmingham.

33 B. Milerski, Pedagogika religii, [w:] Pedagogika subdyscypliny i dziedziny wiedzy o edukacji..., s. 47-68; Tenże, Pedagogika religii, [w:] Religia. Encyklopedia PWN..., s. 53; J. Bagrowicz, Pedagogika religii, [w:] Encyklopedia pedagogiczna XXI wieku..., s. 242-248.

34 B. Milerski, Pedagogika religii, [w:] Religia. Encyklopedia PWN..., s. 53; Tenże, Pedagogika religii, [w:] Pedagogika subdyscypliny i dziedziny wiedzy o edukacji..., s. 47-68; J. Bagrowicz, Pedagogika religii, [w:] Encyklopedia pedagogiczna XXI wieku..., s. 244-248. 
W Wielkiej Brytanii najaktywniejsze są środowiska naukowe bezpośrednio związane z periodykami z zakresu edukacji religijnej, m.in. „The British Journal of Religious Education", "Retoday" oraz "Journal of Beliefs \&Values: Studies in Religion and Education", a także działają stowarzyszenia i organizacje pedagogiczno-religijne The Professional Council for Religious Education i Christian Education. Zostały również powołane instytucje badawcze The Culham College Institute i Welsh National Center for Religious Education prowadzone przez L. J. Francisa oraz Warwick Religions and Education Research Unit kierowane przez R. Jacksona, prowadzące międzynarodowe badania w zakresie edukacji religijnej na styku polityki i kultury ${ }^{35}$.

Polska pedagogika religii otrzymała mocny intelektualny impuls na początku lat dziewięćdziesiątych XX wieku. W 1990 roku została powołana sekcja pedagogiki religii na Wydziale Filozoficznym Towarzystwa Jezusowego w Krakowie (dzisiejsza Wyższa Szkoła Filozoficzno-Pedagogiczna „Ignatianum”) przez Władysława Kubika. Od tego momentu termin pedagogika religii został na stałe wprowadzony do słownika nauk społecznych i teologicznych. Następnie, również w Krakowie, zaczęto wydawać „Rocznik sekcji Pedagogiki Religijnej”, ,Horyzonty Wychowania”, oraz powołano serię wydawniczą „Biblioteka Pedagogiki Religijnej". Ośrodek ten spowodował powstanie przestrzeni merytorycznej dyskusji dotyczącej zakresu współpracy teologii i pedagogiki na poziomie akademickim. Drugim bardzo istotnym impulsem dla rozwoju polskiej pedagogiki religii było powołanie Zakładu Edukacji Chrześcijańskiej w Instytucie Pedagogiki UMK w Toruniu, której kierownikiem został Jerzy Bagrowicz. Kolejnym krokiem było założenie w 1997 roku pod redakcją Bagrowicza czasopisma „Peadagogia Christiana", na łamach którego trwały interdyscyplinarne prace łączące zakres teologii i pedagogiki, a także widoczna była próba przezwyciężenia konfesyjnych ograniczeń. Trzecim impulsem było powołanie w Chrześcijańskiej Akademii Teologicznej w Warszawie katedry pedagogiki religii, której kierownikiem został Bogusław Milerski. Była to inicjatywa tym istotniejsza, że skupiała badaczy edukacji religijnej spoza środowiska katolickiego, co umożliwiało zrównoważenie intelektualnych prac w zakresie całego chrześcijaństwa. Kolejne lata przyniosły dalszy rozwój, m.in. w 2001 roku Jerzy Bagrowicz powołał Zakład Katechetyki i Pedagogiki Religii na Wydziale Teologii UMK, a rok później Cyprian Rogowski katedrę o tej samej nazwie na Wydziale Teologicznym Uniwersytetu Warmińsko-Mazurskiego w Olsztynie. W tym samym czasie w Poznaniu na UAM wydzielono Zakład Pedagogiki Chrześcijańskiej i Dialogu, prowadzony przez Romualda Niparko. Kulminacją i potwierdzeniem międzynarodowego zasięgu polskiej pedagogiki religii było powołanie przez Cypriana Rogowskiego przy współpracy z Katolickim Uniwersytetem Lubelskim i Uniwersytetem w Wiedniu czasopisma

35 B. Milerski, Pedagogika religii, [w:] Religia. Encyklopedia PWN..., s. 53-54; Tenże, Pedagogika religii, [w:] Pedagogika subdyscypliny i dziedziny wiedzy o edukacji..., s. 55-68. 
„Keryks", zamieszczającego aktualne badania w polsko- i niemieckojęzycznej wersji ${ }^{36}$.

Pedagogika religii w ostatniej dekadzie otrzymała instytucjonalne i organizacyjne podstawy, na których możliwy jest rozwój w bardzo szerokim spektrum przedmiotowym. Badacze w tym czasie podejmowali próby (...) recepcji dorobku europejskiej pedagogiki religii, zwłaszcza niemieckojęzycznej, wypracowali teoretyczne podstawy edukacji religijnej w różnych środowiskach dydaktycznych (parafii, szkole, grupach rówieśniczych itp.), podjęli zagadnienia edukacji religijnej w społeczeństwie pluralistycznym, pedagogiczny status nauczania religii w szkole czy wychowawczego wymiaru pracy szkoły ${ }^{37}$. Nawiązała się również ścisła współpraca polskich i niemieckich pedagogów, której owocem od 2009 roku są coroczne polsko-niemieckie Kongresy Pedagogiki Religii, a także tworzenie międzynarodowego czasopisma „Keryks”38.

W całej przestrzeni dyskursywnej pedagogiki religii przełomu XX i XXI wieku, jako dziedziny krytycznej wobec współczesnych przemian kulturowo-społecznych, wyłania się na plan pierwszy silna tendencja do poszukiwania aktualnych treści i narzędzi przekazu. Prace te są obecne szczególnie w zakresie współczesnych dyskusji nad kształtem tzw. teorii, koncepcji, nurtów czy modeli dzisiejszej edukacji religijnej. Wielość pojęć w tym przypadku sprowadza się jednak do dwóch kluczowych zagadnień, mianowicie, na jakich teoriach edukacyjnych powinna się dziś opierać edukacja religijna oraz jakimi narzędziami bądź metodami winna się posługiwać $w$ transmisji własnych treści. Obie sprawy są ze sobą nierozerwalnie powiązane, gdyż najczęściej konkretna teoria pociąga za sobą stosowanie konkretnej metody lub narzędzia teoriopoznawczego. Również od wybranej teorii uzależniony jest wymiar przedmiotowy, gdzie wyznaczona zostaje konkretna relacyjność między szczegółowymi dziedzinami nauk, a w tym przede wszystkim między teologią i pedagogiką.

\section{Badania krytyczne w pedagogice religii}

Druga połowa $X X$ wieku dla pedagogiki religii była czasem szybkiego rozwoju i wchodzenia w badawcze związki z innymi naukami. Niemcy, jak również Austria, Szwajcaria, Wielka Brytania, USA, kraje skandynawskie oraz Polska to tylko przykłady miejsc, gdzie na gruncie protestantyzmu, katolicyzmu czy anglikaniz$\mathrm{mu}$ namysł pedagogiczno-religijny stał się nader istotny dla rozumienia współczesnych przemian kulturowo-społecznych. Jednocześnie źródłowy rozwój pedagogiki religii nieustannie wiązał się z praktyczną analizą miejsca i roli religii $\mathrm{w}$ życiu codziennym, pierwotnie $\mathrm{w}$ wymiarze indywidualnym, następnie w wymiarze wspólnotowym, a w konsekwencji również w wymiarze społecz-

\footnotetext{
${ }^{36}$ C. Rogowski, Pedagogika religii, [w:] Leksykon pedagogiki religii..., s. 561-565.

B. Milerski, Pedagogika religii, [w:] Religia. Encyklopedia PWN..., s. 54.

38 C. Rogowski, Czasopisma pedagogicznoreligijne niemieckojęzyczne, [w:] Leksykon pedagogiki religii...,
} s. 89-90. 
nym. Związki między nauczaniem religii w szkołach a kształceniem równoległym w pluralistycznym społeczeństwie z czasem stały się główną kategorią opisu i tematem prac pedagogiczno-religijnych. Pojawienie się prac z zakresu nauk społecznych, które jednocześnie obejmowały przedmiotowo pojęcie religii, wyznaczyło nową przestrzeń, $\mathrm{w}$ której szeroko rozumiana edukacja religijna musiała zostać na nowo zdefiniowana. Jest tu mowa przede wszystkim o relacji edukacji religijnej wobec takich kategorii, jak: rozwój człowieka w procesie wychowania $i$ nauczania, rodzina, zmiana społeczna, pluralizm społeczny, komunikacja czy wspótczesne media, a także wielu innych wspótczesnych zjawisk społecznych ${ }^{39}$. Dzięki współczesnym naukom społecznym, a szczególnie psychologii ogólnej i psychologii rozwoju człowieka, ujawniło się ważne zadanie i miejsce w całościowym procesie wychowania i nauczania dla pedagogiki religii. Czym jest i jak jest rozumiane $w$ tym kontekście całościowe wychowanie i nauczanie oraz jakie miałoby być zadanie dla pedagogiki religii, to kluczowe pytania poniższego tekstu. Proces nauczania i wychowania jest tu rozumiany jako całokształt zabiegów mających na celu ukształtowanie człowieka w obrębie fizycznym, intelektualnym, moralnym, duchowym, czy religijnym ${ }^{40}$.

Człowiek w tym przypadku po pierwsze jest rozumiany jako nierozerwalna i całościowa struktura psychofizyczna, potrzebująca rozwoju w każdej sferze swojego życia. Jest to o tyle istotne założenie całego procesu edukacji, gdyż pomysły na kształcenie i rozwój osobowości ludzkiej tylko w określonych przestrzeniach zawsze uwarunkowane są konkretną treścią ideologiczną bądź polityczną, których to tylko $w$ historii $X X$ wieku było wiele, np: faszyzm - wychowanie człowieka $\mathrm{w}$ narodowym socjalizmie (dla narodu), nazizm - wychowanie człowieka w obrębie kategorii rasy (dla wybranej „rasy”), czy komunizm - wychowanie człowieka w świeckiej wspólnocie (dla dobra wspólnego). To tylko niektóre przykłady jawnych ideologii edukacyjnych, które w intencjonalny sposób redukowały antropologię do przestrzeni i form dla siebie ideowo i praktycznie korzystnych. Co ciekawe, w powyższych dwudziestowiecznych przykładach kategoria religii nie zawsze była redukowana bądź wykluczana (stalinizm, komunizm itp.), ale niekiedy pojęcie to $\mathrm{w}$ systemowy sposób było również wykorzystywane dla uzasadnienia ideologicznej treści oraz praktycznych celów (nazizm, faszyzm itp.). Całościowa i integrująca struktura wychowania w tym przypadku jawi się jako alternatywa wobec jawnie ideologicznego wychowania, zarówno w indywidualnej

39 Dookreślenie przestrzeni badań krytycznych zostało tu dokonane na podstawie najbardziej aktualnych dyskusji na gruncie polskiej pedagogii religii. Zob. B. Śliwerski, Pedagogika, [w:] Encyklopedia pedagogiczna XXI wieku..., s. 100-102; J. Bagrowicz, Pedagogika religii, s. 242-249; Tenże, Pedagogika chrześcijańska, ibidem, s. 121-125; Z. Marek, Religia w szkole, ibidem, s. 222-223; A. Rynio, Wychowanie religijne, ibidem, s. 456-457; J. Niewęgłowski, Wychowane chrześcijańskie, ibidem, s. 333-335; J. Mastalski, Wychowanie w kulturze chrześcijańskiej, ibidem, s. 482-487. Należy tu jednak zaznaczyć, że wymieniona problematyka z pewnością nie wyczerpuje całej przestrzeni badań krytycznych, ale jest raczej przykładem najbardziej aktualnych dyskusji w tym wymiarze.

40 J. Bagrowicz, Pedagogika religii, [w:] Encyklopedia pedagogiczna XXI wieku..., s. 243-244. 
przestrzeni wolności i rozwoju każdego człowieka, jak również w wymiarze wspólnot lokalnych i całych społeczeństw ${ }^{41}$.

Po drugie zakłada się tu, że struktura psychiczna człowieka potrzebuje przygotowania, wprowadzenia w przestrzeń i interakcje społeczno-kulturowe, które następnie umożliwiają dalszy rozwój osobowościowo-społeczny jednostki. Przestrzeń ta $\mathrm{w}$ sensie historiozoficznym zawsze uwarunkowana jest konkretnymi regułami, normami czy zasadami danego społeczeństwa. Reguły i normy, pod którymi w sposób jawny bądź ukryty obecne się konkretne wartości pochodzące z danej etyki, są również podstawowymi treściami nauczania w zakresie edukacji religijnej. Nie jest tu mowa o pojęciach teologicznych przynależących do danej religii czy konfesji, które najczęściej są pierwotną treścią nauczania w tradycyjnie rozumianej edukacji religijnej. Jest tu mowa o współczesnej edukacji otwartej i nierozłącznie związanej z pojęciami z zakresu aksjologii, mianowicie: tolerancją, szacunkiem wobec drugiego człowieka, odpowiedzialnością, umiejętnością dialogu oraz świadomością uczestnictwa i tworzenia kultury, itp.

Po trzecie, w człowieku znajduje się sfera przestrzeni osobistej, wyrażającej się w życiowym realizowaniu wolności i potrzebie samostanowienia. Sfera ta również wymaga uświadomienia, wydobycia i uczenia egzystencjalnej realizacji. Rozwinięcie jej powoduje wzmocnienie zachowań rozumnych, przewidywalnych i spójnych, ale również dokonywanie wyborów światopoglądowych, wybieranie postaw moralnie i społecznie akceptowalnych. Również tu religia i związana z nią edukacja nie tylko wprowadza i uzasadnia powyższe pojęcia czy wartości, ale przede wszystkim wypracowuje wewnętrznie spójną systemową antropologię. Ona to, jak się wydaje, odpowiada na aktualne potrzeby danych jednostek w określonym społeczeństwie - odpowiada nie tyle na społeczne, ale właśnie na indywidualne czy personalne potrzeby człowieka. Potrzeby te najczęściej związane są z próbą uchwycenia i rozumienia egzystencjalnie najważniejszych pytań, takich jak cel czy sens własnego życia, kontekst istnienia wartości i relacja wobec szeroko rozumianej transcendencji ${ }^{42}$.

Wydaje się więc, że w kształtowaniu i rozwoju osobowości człowieka wychowanie religijne może być elementem wzbogacającym i poszerzającym rozumienie siebie, innych i świata zewnętrznego. Należy tu jednak bardzo wyraźnie zaznaczyć, że dzieje się to tylko w zakresie krytycznej pedagogiki religii, która entymematycznie przyjmuje założenie, iż celem każdej edukacji jest umożliwienie człowiekowi osiągnięcia autonomii i wolności, które prowadzą do wewnętrznej dojrzałości. Założenie to dotyczy całej edukacji, a w tym również edukacji religijnej, w której najważniejszym celem wydaje się być możliwość samodzielnego zbudowania w człowieku osobowości o dojrzałej strukturze religijnej. Jest to sformułowanie zaczerpnięte z psychologii religii, oznaczające osobowość, która z jed-

\footnotetext{
${ }^{41}$ Jednocześnie refleksja ta jest budowana w świadomości, iż edukacja religijna $\mathrm{w}$ istocie swojej bezpośrednio wiąże się również z szerokim horyzontem uwarunkowań ideologicznych, których źródłem może stać się również sama religia. Zob. Pedagogika, red. B. Milerski, B. Śliwerski, s. 241-242.

42 J. Bagrowicz, Pedagogika religii, [w:] Encyklopedia pedagogiczna XXI wieku..., s. 244-247.
} 
nej strony charakteryzuje się stałą i określoną strukturą treściowo-normatywną, z drugiej zaś ma charakter otwarty, procesualny, z założenia emancypacyjny, uznający za priorytet wolność i niezależność własnej osoby względem wszelkich struktur kulturowo-społecznych, w tym również struktur w obrębie danej religii. Jest to o tyle istotne założenie, iż poszukiwana tu tożsamość i zgodność między wymiarem religijnym a psychologicznym dokonuje się wyłącznie w obrębie dojrzałej psychiki człowieka, która bardzo często stoi w sprzeczności względem różnych heteronomicznych, tradycyjnych, konserwatywnych czy fundamentalnych form życia religijnego. Możliwość transponowania treści z religii do życia codziennego i odwrotnie, co skutkuje rozwojem autonomicznej osobowości człowieka, jak się wydaje, jest możliwe przede wszystkim poprzez otwartość i gotowość na zmianę, poczucie własnej tożsamości i wartości oraz umiejętności intrapersonalnego i społecznego dialogu $\mathrm{u}^{43}$.

Stan dojrzałej religijności pozwala na budowanie elastycznej struktury psychicznej, która zapewnia możliwość nieustannego rozwoju przede wszystkim w wymiarze intelektualnym, psychicznym, aksjologicznym czy duchowym. W tym przypadku bogate uzasadnienie, utrwalenie i hierarchizowanie na poziomie wartości moralnych obecne $\mathrm{w}$ treściach religijnych możne skutkować uporządkowaniem i uwewnętrznieniem norm, wartości w codziennym życiu człowieka. Umożliwia to nie tylko kontestację czy niezgodę na normy i zasady niespójne z przekonaniami jednostki a wynikające z relacji społecznych, ale również tworzenie własnego systemu wartości pogłębiającego wewnętrzną tożsamość i poczucie własnej wartości. Idąc dalej, obecna w edukacji religijnej sakralizacja wartości oraz odnajdowanie wewnętrznego sensu będącego odpowiedzią na przemijalność życia i nieuchronność ludzkiej śmierci może być czynnikiem wzmacniającym poczucie bezpieczeństwa i stabilizację emocjonalną. Również wprowadzenie transcendentnego układu odniesienia, wyższego sensu czy meta-prawa obecnego w religii w pojęciu Boga, może skutkować zgodą i otwartością na własny los oraz na tzw. sytuacje graniczne obecne w życiu poprzez cierpienie, śmierć czy chorobę ${ }^{44}$.

Kolejną ważną kwestią dla badań krytycznych w pedagogice religii jest relacja między treściami edukacji religijnej a życiem człowieka w wymiarze rodzinnym ${ }^{45}$.

\footnotetext{
43 Istnieje bezpośrednia korelacja między religijnością niedojrzałą a ideologicznymi formami kulturowo-społecznego uczestnictwa, gdzie im wyższy stopień religijności niedojrzałej, tym wyższe prawdopodobieństwo wykorzystania religii jako ideologii społeczno-politycznej. Proces ten może prowadzić do edukacji jawnie ideologicznej. Zob. Z. Chlewinski, Religijność dojrzała i niedojrzała..., s. 111-115; Pedagogika, red. B. Milerski, B. Śliwerski, s. 241-242.

44 Świadomie jest tu pomijany fragment problematyki badań krytycznych wyrażający się w analizach wskazujących na niekorzystne psychologicznie konsekwencje oddziaływania religii na psychikę człowieka, z uwagi na powyższe wprowadzenie kategorii religijnie dojrzałej psychiki. Zob. J. Bagrowicz, Pedagogika religii, [w:] Encyklopedia pedagogiczna XXI..., s. 243-249; Z. Chlewiński, Religijność dojrzała i niedojrzała..., s. 105-114.

45 Intencjonalnie pomija się tu dyskusję wokół samej definicji rodziny uznając, iż problematyka ta wymaga osobnej szczegółowej analizy, na którą w tym miejscu nie ma miejsca.
} 
Niezależnie od interpretacji współczesnej kondycji rodziny - której ocena przeważnie wynika z ideowych założeń, najczęściej wynikających z danego systemu religijnego bądź światopoglądowego - istnieje pewna tożsamość treści wchodzących w skład rodziny i religii. Obie te kategorie korelują w co najmniej dwóch przestrzeniach: indywidualnym, gdzie rodzina jest elementem pierwotnym i analizowana jest niezależnie od struktury społecznej, jak i religijnej. Jest tu mowa o wszelkich przejawach życia religijnego w praktyce niezależnej od Kościoła czy wspólnoty religijnej, a mającej wpływ na wewnętrzną egzystencję rodziny. Druga przestrzeń to poziom społeczny, w którym rodzina nie tylko istnieje, ale również warunkuje i jest warunkowana w życiu społecznym i religijnym. Wymiar pierwszy ukazuje korelację między rodzinną praktyką religijną a rozwojem rodziny, zaś drugi z szeroko rozumianą wspólnotową praktyką religijną i jej społecznymi konsekwencjami ${ }^{46}$.

Ponownie religijność, o której jest tu mowa, z założenia związana jest z wymiarem religijności dojrzałej, która, jak się wydaje, wpływa na horyzont rozumienia i egzystencji rodziny niezależnie od przyjmowanej roli $\mathrm{w}$ strukturze uczestnictwa. Co więcej, procesy, o których jest tu mowa, bezpośrednio oddziałują na członków rodziny nie tylko, gdy są wynikiem świadomych zamiarów, planów lub czynów, ale również, gdy są nieświadome, ale spójne z danym systemem działań i celów. Chodzi tu przede wszystkim o wszelkie transponowanie treści hierarchii społecznej, porządku natury, prawa pierwszeństwa, role wewnątrzwspólnotowe, prawa jednostki itd., które źródłowo zapośredniczają $\mathrm{w}$ treściach teologicznych, a mają również znaczenie egzystencjalne lub wręcz praktyczne w życiu rodziny. Przykładami będą tu: wspólne posiłki całej rodziny interpretowane jako wyraz integracji i ważności każdego z jej członków; wspólna modlitwa jako wyraz świadomości wspólnych celów i potrzeb oraz równości wobec prawa, czyli wobec transcendencji; wzmocnienie autorytetu rodziców w obrębie struktury porządku i hierarchii wynikającej z treści teologicznej; ale także wyjątkowość i indywidualność każdego członka rodziny niezależnie od zajmowanego miejsca czy wykonywanej roli, analogicznie do sytuacji w strukturze wspólnoty religijnej czy Kościoła. Analiza ta odnosi się przede wszystkim do wymiaru jednostkowego, personalnego, gdzie treści edukacji religijnej z jednej strony wpływają na codzienną praktykę życia całej rodziny, ale również z drugiej strony wyznaczają cele i zadania, a przez to i normy działania. Normy te z kolei obowiązują w różny sposób, ale wszystkie jednostki, czyli wszystkich członków rodziny, co w konsekwencji odsłania kolejny wymiar współdziałania kategorii religii i rodziny, mianowicie wymiar socjalizacji.

Jak już była mowa powyżej, przykłady wzajemnego oddziaływania religii na rodzinę i odwrotnie mogą wspomagać harmonijny i integralny rozwój rodziny, jak i człowieka, przede wszystkim, gdy religijność, zwłaszcza w wymiarze wspólnotowym, opiera się na dojrzałych kryteriach i normach. Kryteria te wprost wyni-

46 J. Bagrowicz, Pedagogika religii, [w:] Encyklopedia pedagogiczna XXI wieku..., s. 245-246. 
kają z dojrzałej psychiki religijnej, opartej na autonomiczności i wolności każdego człowieka względem danego Kościoła czy wyznania. To z kolei przekłada się na autonomię jednostek wobec rodziny jako całości oraz suwerenność, zależną od wieku i sytuacji egzystencjalnej członków rodziny, ale niezbywalnie przynależącą każdej osobie w rodzinie ${ }^{47}$.

Istnieje duża korelacja między treścią teologiczną w zakresie nauki społecznej większości kościołów chrześcijańskich a potrzebami społecznymi rodziny jako elementu struktury społecznej. Związek ten polega na szeroko rozumianej socjalizacji, czyli pierwotnie na włączeniu jednostki w strukturę rodziny, a następnie rodziny w strukturę społeczną i równolegle w strukturę wspólnoty religijnej. Rodzina jest tu rozumiana nie tylko jako suma jednostek uczestniczących, ale przede wszystkim jako byt częściowo niezależny, wykraczający poza ilościowe rozumienie danego zbioru. Byt ten charakteryzuje się własną strukturą relacyjności, indywidualnymi normami i wartościami moralnymi. Zarówno od strony społecznej, jak i religijnej rodzina jest podmiotem oddziaływań, co oznacza, że jest traktowana jako cel sam w sobie - cel ponadjednostkowy. Jest kształtowana w zakresie praw, obowiązków, przywilejów, celów społecznych i religijnych, które ukierunkowane są na jej wewnętrzny rozwój i częściową niezależność względem innych bytów społecznych czy religijnych. Istnieje również kontekst przedmiotowego rozumienia rodziny, zarówno na gruncie społeczno-politycznym, jak również na gruncie religii - Kościoła. W tym przypadku rodzina staje się argumentem szeroko rozumianej walki o władzę, przez co zostają uprzedmiotowione nie tylko jej potrzeby czy wewnętrzne cele, ale również - co wydaje się jeszcze bardziej ukryte i częściowo nieświadome - staje się elementem ideowym, będącym jawną treścią ideologicznej edukacji zarówno powszechnej, jak i religijnej.

Kolejnym ważnym elementem badania i analizy krytycznej zarówno w edukacji religijnej, jak i edukacji powszechnej, jest kategoria współczesnego społeczeństwa, jako społeczeństwa pluralistycznego. Dzisiejsze społeczeństwo nie tylko charakteryzuje się zwiększoną dynamiką komunikacyjną, wysoką technologią, szybkim przesyłem informacji itp., ale przede wszystkim niespotykaną jak dotąd w historii otwartością i przenikalnością treści kulturowych społeczeństw lokalnych, które składają się na społeczeństwo globalne. Jest to proces wielopłaszczyznowy i niejednorodny w skali całego globu, jednak w tej dynamicznej strukturze nieustannych zmian dokonujących się w społeczeństwie XXI wieku człowiek jak nigdy dotąd pilnie potrzebuje sposobu, narzędzia czy też języka rozumienia otaczającej go rzeczywistości. Szybkie zmiany społeczne niosą za sobą konkretne skutki, np. wyobcowania i alienacji, gdzie narzędzie rozumienia zmian daje nie tylko pierwotny ogląd świata, ale także umożliwia znalezienie własnego miejsca. Z uwagi na to wiedza pochodząca zarówno z edukacji powszechnej, jak i edukacji

\footnotetext{
47 Aspekt uprzedmiotowienia rodziny jako kategorii politycznej w wymiarze edukacji powszechnej i religijnej nie jest tu przedmiotem szczegółowej analizy, natomiast należy zaznaczyć, iż kontekst ten najczęściej jest bezpośrednio związany z kategorią religijności niedojrzałej lub nie w pełni dojrzałej. Zob. Z. Chlewiński, Religijność dojrzała i niedojrzała..., s. 115-119.
} 
religijnej wydaje się dla człowieka nie tylko możliwością, ale i koniecznością dla zbudowania jak najszerszego horyzontu rozumienia. To rozumienie, ta szeroka perspektywa oglądu tego, co nas tu i teraz otacza, wymaga epistemicznej metody oglądu zjawiska z różnych stron i różnych perspektyw, z różnych światopoglądów i różnych moralności. Jest to metoda trudna, niekiedy uznawana za utopijną, ale, jak się wydaje, nie wynika z założeń teoretycznych, lecz z życiowej potrzeby człowieka XXI wieku. To szerokie rozumienie świata i siebie ma pozwolić na zbudowanie światooglądu możliwie wolnego od stereotypów, mitów czy dogmatów kulturowych, społecznych, jak również religijnych. Powyższy rys epistemologiczny ukazuje wzajemną przenikalność celów i zadań edukacji powszechnej i religijnej względem kategorii społeczeństwa pluralistycznego ${ }^{48}$. Występuje tu również intensywna korelacja między wymiarem społeczeństwa pluralistycznego a współczesnymi religiami. Relacja ta polega na hermeneutycznej zależności występującej w kulturze XXI wieku między społeczeństwem globalnym a religiami świata, gdzie pedagogika religii $\mathrm{w}$ tym przypadku poprzez wewnętrzny kontekst analiz ujawnia wzajemnie relacje i zależności między powyższymi przestrzeniami. Hermeneutyka powiązań ma co najmniej kilka aspektów, jednak na pierwszy plan wyłania się aspekt socjalizacyjny, gdzie pedagogika religii, opierając się na nauce społecznej danego kościoła lub wyznania, ogniskuje badawczą uwagę, stara się odpowiedzieć na aktualne pytania i rozwiązać współcześnie najbardziej palące problemy danej grupy wyznaniowej jako społeczności lokalnej. Społecznym skutkiem takiego działania możne być bardziej świadome, gdyż wciąż aktualizujące się i refleksyjne rozumienie szybkich zmian społecznych. $W$ tym przypadku religia bezpośrednio oddziałuje na człowieka w jego realnym "tu i teraz", czyli obecnej egzystencji, modyfikując społeczeństwo w wymiarze lokalnym, a następnie w wymiarze globalnym. Istnieje jednak druga strona powyższego oddziaływania, gdzie pluralizm i wciąż rosnąca różnorodność społeczno-kulturowa nie tylko jest wyzwaniem dla edukacji religijnej, ale także jest przyczyną i motorem dla wewnętrznych przemian w jej strukturze. Jak się wydaje, oznacza to, że nie tylko edukacja religijna ma potencjał wpływania na rozumienie współczesnego świata przez człowieka poprzez poszerzanie sfery świadomego uczestnictwa $\mathrm{w}$ nim, ale również religie $\mathrm{w}$ wymiarze edukacyjnym są mobilizowane do wewnętrznego rozwoju i przeformułowywania własnego języka przekazu, a niekiedy również własnych teorii i dogmatów. W tym przypadku religie świata stymulują, jak i są stymulowane do rozwoju przez otaczający świat, a współczesna edukacja religijna staje się jednocześnie jednym z hermeneutycznych narzędzi rozumienia świata i człowieka ${ }^{49}$.

W tej dynamicznej strukturze współczesnego społeczeństwa pojawia się również kwestia nowych ruchów religijnych, gdzie edukacja religijna, a w niej szczególnie pedagogika religii, może spełniać dość istotną rolę. Jest tu mowa przede

\footnotetext{
48 J. Bagrowicz, Pedagogika religii, [w:] Encyklopedia pedagogiczna XXI wieku..., s. 248.

49 Ibidem.
} 
wszystkim o rzetelnej wiedzy na temat nowych wspólnot i wyznań wewnątrz konkretnych religii, ale również o grupach o charakterze izolacyjnym czy sekt ideologicznych. $W$ tej kwestii współczesne media i zaawansowana technika komunikacyjna spełniają dwojaką funkcję, z jednej strony są źródłem bardzo bogatej i szybko dostępnej wiedzy na temat religii świata i nowych ruchów religijnych, która jeszcze kilkanaście lat wcześniej wymagałaby długich i żmudnych poszukiwań i studiów. Natomiast z drugiej strony źródła te mogą służyć powielaniu niesprawdzonych i nierzetelnych informacji, co może skutkować rozprzestrzenianiem się organizacji i grup psychologicznie niebezpiecznych, które mają strukturę organizacyjną o kształcie i kryteriach działania sekty kognitywnej, emocjonalnej lub psychologicznej.

Obok kontekstu badań społecznych, filozoficznych i psychologicznych istnieją przykłady badań krytycznych, których przedmiotem jest sama dydaktyka i metodologia edukacji religijnej. We współczesnej pedagogice religii idąc tropem Bogusława Milerskiego można wyróżnić kilka co najmniej głównych problemów metodologicznych i przedmiotowych, wchodzących w skład krytycznego, naukowego dyskursu edukacyjnoreligijnego. Pierwszym jest dyskusja w zakresie aktualnego statusu naukowego i metodologicznego pedagogiki religii, polegającego na poszukiwaniu teoretycznych fundamentów i empirycznych uzasadnień w zakresie teorii nauki i metodologii badań. Drugim jest polemika wokół wzajemnego wkładu pedagogiki religii i teorii kształcenia ogólnego, który zawiera się $\mathrm{w}$ analizach korelacji zarówno teorii, jak i narzędzi między powyższymi wymiarami edukacji. Trzecim zaś polem dyskusji jest relacja pedagogiki religii i edukacji międzykulturowej, jako wspólnego intelektualnego wysiłku prowadzącego do odpowiedzi na współczesne potrzeby społeczeństwa pluralistycznego ${ }^{50}$.

\section{Zakończenie}

Obok wymienionych powyżej współczesnych problemów i dyskusji w zakresie krytycznej pedagogiki religii istnieje dużo więcej kwestii i zagadnień, które w tym tekście nie zostały podjęte. Istotą jednak badań krytycznych w tym też miejscu jest dostrzeżenie momentów wykorzystywania problematyki religijnej do niejawnych celów edukacyjnych, zazwyczaj całkowicie wykraczających poza przestrzeń problematyki wychowania i kształcenia. Przykładem może być tu budowanie, jak się wydaje, sztucznej opozycji czy też dychotomii między porządkiem edukacji powszechnej i religijnej. Podziały te najczęściej wynikają z politycznych bądź ideowych przesłanek oraz zazwyczaj opierają się na redukcji i zawężaniu możliwości poznawczych człowieka, odrzucając założenie kumulatywnej teorii wiedzy. W tym oto miejscu integrująca, łącząca czy holistyczna for-

50 B. Milerski, Pedagogika religii, [w:] Pedagogika subdyscypliny i dziedziny wiedzy o edukacji..., s. 60-67. 
ma edukacji powszechnej, w skład której niezbywalnie włącza się religię, wydaje się być częściową konsekwencją krytycznych badań w pedagogice religii. Najprościej rzecz ujmując, poprzez wzajemną korelację tych wymiarów edukacji w pierwszym rzędzie można zaobserwować, że w edukacji powszechnej poszerzeniu może ulec analiza świadomych i ukrytych przestrzeni egzystencji sfery wartości aksjologicznej, w edukacji religijnej zaś może skutkować to otwarciem metodologicznym oraz dostępem do źródłowych analiz społeczno-kulturowych. Należy tu jednak przypomnieć, że priorytetem w krytycznym paradygmacie badań religijnych nie jest możliwość ich zastosowania czy też zaadoptowania dla aktualnych potrzeb, ale przede wszystkim budowa samoświadomej i samokrytycznej teorii i praktyki pedagogicznej w sferze życia religijnego człowieka.

\section{Summary}

\section{Critical religious education}

The purpose of this article is to present the genesis and the development of religious education in the aspect of critical paradigm. The main thesis introduces $20^{\mathrm{m}}$ century pedagogical and religious inquiries by means of analysis, primarily involved in the phase of ideological and critical interpretation. A few major traditions connected with religious education are discussed, including American, Anglo-Saxon and German research, established at the beginning of the $20^{\prime \prime}$ century and most intensively developed over the interwar period, due to the demands of liberal theology and emancipation trends. The German analysis appears to be crucial, with its demands of critical review of religious upbringing in Protestant Church in Germany, where they were initiated mainly by educators and school teachers. Religious education based on critical paradigm was not focused on shaping theology, monotheism or even evangelicality then, but above all humanity in its excellent form of its Devine origin. The text not only presents the aspect of critical religious education, but at the same time discusses selected aspects of social, psychological or philosophical research. Therefore, the issues of upbringing and religious education receive wider range of possible criteria and tools enabling its understanding. The research mostly concerns contemporary matters present in Polish religious education and the crucial role is played by the works of C. Rogowski, B. Milerski and J. Bagrowicz. 